\title{
LA RECREACIÓN LITERARIA DE LA EXPERIENCIA BÉLICA: DE LOS MODELOS CLÁSICOS AL NUEVO PARADIGMA DE STENDHAL, CRANE Y TOLSTOI
}

\author{
Javier SÁNCHEZ ZAPATERO \\ Universidad de Salamanca
}

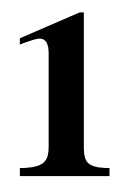

La repetición de la guerra a lo largo de la historia, así como el dramatismo y la intensidad que le aportan su potencial capacidad destructiva y violenta, ha provocado su continua aparición como tópico literario, como demuestra la prolijidad de títulos inspirados por hitos históricos como la Guerra de Troya, las batallas de la Reconquista española, la Guerra de los Cien Años o los grandes conflictos bélicos internacionales acaecidos durante el siglo XX. Según Oliver Lubrich (2006: 371), numerosos autores «abordaron la guerra con intención crítica, [otros] la proveyeron de justificación ideológica, la celebraron estéticamente, minimizaron sus horrores, describieron batallas por el placer de describirlas, o por los efectos de aventura o tensión que podían suscitar». Presentada desde diversos prismas, la guerra ha estado presente, desde sus orígenes, en la literatura:

El héroe y el miles gloriosus, la tragedia y el esperpento, el canto épico y la burla de la caballería feudal no son sino el haz y el envés de casi toda la literatura europea (Martínez, 2003: 137).

También ha contribuido a esta fecundidad la intrínseca vinculación que la experiencia bélica mantiene con la muerte. Como ha observado Claudio Guillén (2006: 253), a pesar de que las actitudes ante el fin de la vida se han ido modificando con el devenir del tiempo -pasando del «hombre medieval que espera a la muerte [...] al dramatismo romántico [y] las protestas ante el morir»-, el fenómeno se ha convertido en un elemento esencial de la cultura universal y, en el ámbito estricto de la literatura, en uno de los temas más fructíferos, hasta el punto de que es posible afirmar que «no existe literatura al margen de la muerte» (Guillén, 2006: 255). Al mostrar la fragilidad de la vida, mostrando la tenue y azarosa frontera que la separa de su clausura definitiva, y el 
enfrentamiento del ser humano por su supervivencia, resulta imposible analizar las relaciones de la experiencia bélica con la literatura sin aludir a su vinculación con la muerte.

La permanencia en semejante contexto, dominado por la violencia y la brutalidad, provoca la transformación del individuo y la consideración de la guerra como una "experiencia límite" en la que los sistemas de valores y creencias quedan trastocados -generando así una "ruptura psíquica catastrófica" o, en palabras de Sebald (2003: 97), «mito de la hora cero»-. Ese carácter excepcional ha sido expuesto a lo largo de la historia de diversas formas, oscilantes entre la exaltación de los ideales de honor, que llevaban a combatir de forma heroica sin apenas prestar importancia a las consecuencias que la acción en la batalla pudiera tener para la propia vida, y la supremacía del miedo -con el rechazo a la batalla que llevaba aparejado- frente a cualquier otro sentimiento. Ante la vorágine de la destrucción, el hombre amenazado se ha visto obligado a elegir entre dos sentimientos tan opuestos como extremos y jamás ha podido permanecer indiferente.

2. En varios de los textos fundacionales de las literaturas clásicas -elevadas ya en la actualidad a la categoría de fuentes culturales gracias a su antigüedad y difusión- está presente el tema de la guerra vinculado a los modelos épicos y, de forma más concreta, a la epopeya. Así, dentro de la tradición sánscrita el gran poema Mahabharata narra la lucha que se establece entre dos dinastías que optaban al trono de un reino situado al norte del río Ganges. Además del relato bélico, la obra -formada por más de doscientos mil versos- incluye leyes y disquisiciones morales y filosóficas. De las dieciocho partes en las que está dividida, sólo cinco están específicamente destinadas a mostrar cómo se produjo la batalla entre los dos ejércitos contendientes. El texto, como todos los legendarios poemas épicos, fue completándose y perfeccionándose a lo largo de varias generaciones hasta convertirse en referente de muchos sectores de la sociedad hindú al ser preservado por escrito en el siglo I d. C.

De forma similar, el tema de la guerra está presente en varios de los primeros testimonios escritos de la lengua hebrea que se conservan, como en el Libro de Josué -integrado en el Antiguo Testamento dentro del grupo de textos a los que se las ha dado el nombre de "Libros históricos"- donde se relata la conquista de la Tierra Prometida por el pueblo de Israel a través de un enfrentamiento armado cuya narración, lejos de limitarse a mostrar la lucha, recoge también la estrategia empleada en combate por los bandos en lid. Según Jordi Balló y Xavier Pérez, la búsqueda de la tierra prometida, la fundación en ella de una nueva patria, y la consiguiente batalla que el cumplimiento de ambos objetivos implica se convertirían en motivos argumentales presentes en 
innumerables tradiciones literarias ${ }^{1}$. Al mostrar las dificultades y la valentía de quienes forjaron los orígenes de una sociedad, así como las señas de identidad que la distinguían e hicieron enfrentarse con el resto de grupos, el proceso de identificación entre el relato y la comunidad que lo ha hecho nacer es siempre notable, pues «la búsqueda de la tierra prometida supone una aventura colectiva, destinada a crear una mitología de fácil comprensión alrededor del germen de un país y del papel que en él ha cumplido la figura del líder» (Balló y Pérez, 2003: 43). De ahí que el modelo narrativo mostrado en los textos bíblicos -presente en un amplio espectro que incluye, entre otros ejemplos, a la Eneida de Virgilio, a las crónicas sobre la conquista de América o a las novelas protagonizadas por los colonos del Oeste americano- se haya repetido de forma frecuente a lo largo de la historia de la literatura bélica, surgida en innumerables ocasiones para fortalecer los vínculos entre una sociedad y las causas por las que ésta entra en combate.

La literatura griega clásica ha legado uno de los más influyentes modelos de la literatura bélica a través del denominado "ciclo troyano" que, compuesto de diversos poemas épicos entre los que se encuentran los textos homéricos Ilíada y Odisea, relataba la leyenda de la guerra de Troya. El enfrentamiento entre los ejércitos griego y troyano aparece como telón de fondo en la Ilíada, que se ocupa de un suceso determinado acaecido en la contienda: el enfrentamiento entre Aquiles y Agamenón y las consecuencias que genera en el desarrollo de la batalla. Además de presentar al principal modelo heroico de la literatura clásica-Aquiles-, la obra destaca por mostrar el carácter destructor y alienador de toda guerra, como demuestra el comportamiento de los personajes de la obra, que alternan actuaciones de una crueldad, una violencia y unas ansias de sangre tan desmedidas como gigantescas con parlamentos serenos y lúcidos:

El verdadero tema, el centro de la Ilíada es la fuerza. La fuerza manejada por los hombres, la fuerza que somete a los hombres, la fuerza ante la cual la carne de los hombres se crispa. El alma humana sin cesar aparece modificada por sus relaciones con la fuerza, arrastrada, cegada por la fuerza de que cree disponer, doblegada por la presión de la fuerza que sufre [...]. La fuerza es lo que hace de quienquiera que le esté sometido una cosa. Cuando se ejerce hasta el fin, hace del hombre una cosa en el sentido más literal, pues hace de él un cadáver. Había alguien y, un instante después, no hay nadie. Es un cuadro que la Ilíada no se cansa de presentar (Weil, 1941: 357).

Para el escritor italiano Alessandro Baricco -autor de Homero, Ilíada, posmoderna relectura del texto clásico caracterizada por la sustitución del narrador omnisciente por la voz en primera persona de los protagonistas y por la eliminación de

\footnotetext{
${ }^{1}$ Para Jorge Luis Borges (2002: 65), los textos homéricos relativos a la historia de Troya y al viaje de Ulises y los referentes a la vida de Jesucristo -en los que, grosso modo, aparecerían reflejadas las citadas características acerca de la consecución de una nueva y mejor era vital- serían, por su radial e inmensa capacidad de influencia, «las tres historias que, durante siglos, le han bastado a la humanidad: la gente las ha contado y las ha vuelto a contar una y otra vez: les ha puesto música, las ha pintado».
} 
las apariciones de los dioses en la historia-, el relato es un «monumento a la guerra» (Baricco, 2002: 180), tanto por la forma en la que muestra la fanática transformación que el combate provoca en el hombre, convertido en un ser sediento de sangre, muerte y destrucción, como por el hecho de mostrar el atractivo estético y existencial de la experiencia bélica:

[La Ilíada] canta la belleza de la guerra, y lo hace con una fuerza y una pasión memorables. No hay casi ningún héroe cuyo esplendor, moral y físico, en el momento del combate, no se recuerde [...]. Durante milenios la guerra ha sido, para los hombres, la circunstancia en la que la intensidad - la belleza- de la vida se desencadenaba en toda su potencia y verdad. Era casi la única oportunidad para cambiar el propio destino, para encontrarse la verdad de uno mismo, para elevarse a la alta conciencia ética. Frente a las anémicas emociones de la vida y a la mediocre estatura moral de la cotidianeidad, la guerra ponía en marcha el mundo y empujaba a los individuos más allá de los límites acostumbrados, hasta un lugar del alma que debía de parecerles a ellos, por fin, el punto de llegada de toda búsqueda, de todo deseo (Baricco, 2002: 184).

El carácter sublime de la experiencia bélica que manifiesta el texto homérico está presente en algunas de las reflexiones filosóficas e intelectuales que el tema de la guerra ha sugerido en el siglo XX. Ludwig Wittgenstein, por ejemplo, se alistó en 1914 en el ejército austriaco para participar como voluntario en la I Guerra Mundial, con la convicción de que los sentimientos experimentados en el frente de batalla le servirían para realizar una introspección en lo más profundo de su ser y llegar así a obtener un mejor conocimiento de sí mismo. Así lo expresó el propio autor, quien afirmaba en una de las anotaciones escritas durante su participación en la contienda, recogidas en el volumen Diarios secretos, que «tal vez la cercanía de la muerte [...] pueda traer la luz de la vida» (Wittgenstein, 2006: 138). Semejante visión de la guerra -presente también en escritores como André Malraux o Ernest Hemingway, para los que las contiendas bélicas y, en general, todas las situaciones conflictivas suponían un atractivo estímulo vital y estético ${ }^{2}$ - aparece acentuada en la obra del escritor y pensador Ernest Jünger. Participante en las dos guerras mundiales, el autor alemán consideraba que el mero

\footnotetext{
${ }^{2}$ Catalogados tradicionalmente como "hombres de acción", Malraux y Hemingway tenían en la guerra y, en general, en las situaciones conflictivas- «su más potente droga literaria», pues ambos sentían «una necesidad carnal e intelectual de ver la historia de cerca para escribir» (Tood, 2001: 282). Sus periplos vitales y sus obras literarias ejemplifican esta atracción por las "experiencias límite". Hemingway participó en la I Guerra Mundial, combatiendo como voluntario en el frente italiano, experiencia que serviría años después de base a su novela Adiós a las armas, y también vivió en directo la Guerra Civil Española, a la que acudió en calidad de periodista -como haría años más tarde en la II Guerra Mundial- y de guionista del documental La Tierra Española. El conflicto español inspiró su obra de teatro La quinta columna, su relato La mariposa y el tanque y su celebérrima novela Por quién doblan las campanas. André Malraux, por su parte, vivió la liberación indochina -en la que mantuvo un importante papel como líder de opinión a través de la dirección del periódico L'Indochine-, la revolución china -contexto histórico en el que se ambienta su novela La condición humana-, la Guerra Civil Española -en la que participó activamente como líder de la escuadrilla aérea "España", cuyas vicisitudes fueron narradas en La Esperanza y en la película Sierra de Teruel- y, por último y desde la resistencia francesa, la II Guerra Mundial.
} 
hecho de experimentar una vivencia tan traumática y violenta como la de la guerra distinguía a unos seres humanos de otros. Según Jünger, sobrevivir en primera línea de batalla y poder hacer frente a una situación tensa, llena de miedo y dolor, supone una diferencia cualitativa entre las personas, como si sólo quienes sufrieron esa experiencia pudieran llegar a sentirse plenamente realizados:

Nosotros somos aquellos que han sufrido, aquellos que han soportado el dolor, pero más allá de esos sufrimientos, todavía podemos reivindicar para nuestra gloria esa profunda emoción que nos embargaba en la batalla, y que es la recompensa de las proezas heroicas conscientemente realizadas [...]. ¡Dichoso el hombre que ha podido sentir esa sublime emoción, tan diferente de la resignación [...] frente al sufrimiento! (Jünger, 1987: 150).

Junto a la idealización -rayana en ocasiones con la exaltación- de la guerra como generador vital, presente de forma continua en Tempestades de acero, la novela que escribió el autor sobre su experiencia como soldado en la I Guerra Mundial, en toda la obra del escritor alemán se muestra el atractivo estético que toda contienda bélica puede suponer, como se expone en este pasaje del segundo volumen de Radiaciones, el libro de diarios que escribió durante la II Guerra Mundial, en el que se interpreta un bombardeo como si de un espectáculo artístico se tratase ${ }^{3}$ :

Dos o tres escuadrillas han virado hacia nuestra casa, se han lanzado hacia ella en línea recta y han descargado sus bombas al pasar por encima [...]. El espectáculo era en verdad embriagador; hacía tambalearse la razón. En estos acontecimientos se alcanza un grado tal que la propia seguridad empieza a volverse secundaria: los elementos de la intuición se intensifican de tal manera que ya no queda sitio para los de la reflexión, ni aun para el miedo (Jünger, 2005: 304).

Además de en la Ilíada, el tema bélico está presente en la tradición griega en numerosos textos de carácter historiográfico. De hecho, a pesar de que en algunas civilizaciones legendarias parecen conservarse primitivos documentos susceptibles de ser considerados textos históricos -así pueden ser considerados los relieves conmemorativos de batallas en Mesopotamia y Egipto o los libros sagrados de las civilizaciones antiguas-, tradicionalmente se ha venido identificando a la figura de Heródoto con la del fundador de la historiografía y, por tanto, su relato sobre las Guerras Médicas como la primera manifestación de la disciplina. Su influencia -y la de Tucídides, responsable de la Historia de la guerra del Peloponeso, en la que se daba cuenta del conflicto mantenido entre Atenas y Esparta- no sólo provocó el desarrollo de las obras históricas en la civilización romana, sino que además hizo que su modelo de escritura, basado en el mantenimiento de una posición moral fiable sobre el sentido de

\footnotetext{
${ }^{3}$ Además de con la propia fascinación que la guerra, en cuanto experiencia intensa y novedosa, puede suponer, los sentimientos que suscita en Jünger el bombardeo se han de relacionar con su admiración por los avances científicos y técnicos que trae consigo el progreso, tema constante en toda su obra.
} 
los acontecimientos públicos, y no una mera dedicación empírica a las verdades de hecho y a las fuentes, se convirtiera en el utilizado por autores como Suetonio, Julio César o Tito Livio. La fertilidad de la disciplina en la época romana puede ser detectada a través de hitos como la creación de los Anales o las reflexiones que sobre su composición plantea Cicerón, en las que se pone de manifiesto la relación entre los textos históricos y los épicos:

Es verdad que la sucesión cronológica de los anales por sí misma nos atrae sólo medianamente, como si se tratara de una enumeración de fechas del calendario, por el contrario, las peligrosas y cambiantes vicisitudes de un hombre extraordinario con frecuencia despiertan admiración y suscitan el interés, la alegría, la pesadumbre, la esperanza y el miedo; si encima concluyen con un desenlace sorprendente, el espíritu rebosa con el agradable deleite de la lectura (Cicerón, 1996: 212).

Las palabras del pensador romano, tomadas de su tratado Sobre las leyes, evidencian cómo en la época clásica la preocupación principal de quienes abordaban textos históricos no se refería a la veracidad y a la exactitud de los hechos -pues se escribía sobre acontecimientos públicos, conocidos por gran parte de la sociedad-, sino, más bien, a la obligación de relatar hechos significativos por su carácter ejemplar. Los modelos épicos a los que parece aludir la cita de Cicerón pueden, por sus características formales, atraer de forma más efectiva a los receptores de los textos y, por tanto, cumplir mejor con su función moralizante a pesar de que acostumbren a referirse a sucesos legendarios -que, no obstante, suelen partir de una base real-. Tal y como ha demostrado Georges Duzémil, las narraciones épicas están estrechamente vinculadas con los mitos cosmogónicos que las diversas culturas han generado, por lo que resulta incorrecto otorgarlas una dimensión meramente historicista.

Aunque, en sentido estricto, la épica es el nombre con el se designa a los «relatos en los que se narran acciones de "héroes" que representan los ideales de una clase guerrera o aristocrática y de toda una sociedad que asocia a dichos héroes con sus orígenes y destino como pueblo» (Estébanez Calderón, 2002: 335) y, consecuentemente, su espectro temático es amplísimo, resulta evidente que la guerra es uno de los asuntos que con mayor frecuencia aparece en ellos. Su condición de forma habitual de relación entre los pueblos, y su habitual vinculación tanto con los acontecimientos fundacionales de diversas civilizaciones como con las acciones protagonizadas por personajes heroicos, hace que en prácticamente todos los modelos épicos existentes en la historia de la literatura sea desarrollado el tema bélico.

Junto a los modelos greco-latinos, los textos épicos de mayor importancia en la cultura occidental pertenecen a la tradición medieval. Tanto la cultura germánica -de la proceden obras como Beowulf, el gran poema fundacional de la literatura inglesa, el Cantar de los Nibelungos, obra determinante en el desarrollo de las letras alemanas o 
las sagas, narraciones en prosa centradas en acontecimientos protagonizados por familias reales creadas en los países escandinavos- como la románica-germen de los "cantares de gesta"- han aportado textos de carácter épico en los que, en mayor o menor medida, aparecía la guerra como motivo fundamental del argumento. Así, en la literatura francesa la Chanson de Roland se ocupa de un acontecimiento histórico acaecido en el siglo VIII -la derrota del ejército de Carlomagno en la batalla de Roncesvalles-, conveniente transformado en la obra en un legendario enfrentamiento en el que, a modo de cruzada, los originarios soldados vascones y aragoneses pasan a ser sarracenos contra los que ha de luchar el ejército galo. También en torno a una figura heroica aparece en la literatura española el Poema de Mío Cid, en el que, junto a temas típicos de la épica, como los de la recuperación del honor o la afirmación de los valores de la clase social responsable de su gestación -en este caso, la baja nobleza castellanaaparecen los de la integridad moral y la condición de buen soldado del Cid, pues toda creación épica acostumbra a «exaltar los propósitos y conducta de los hombres que han realizado hechos notables y que se recuerdan por su ejemplaridad» (López Estrada y López García-Berdoy, 1991: 53). En consecuencia, se relatan en el poema los combates del ejército del Cid contra el de los moros, llegando a detallar los enfrentamientos individuales entre miembros de uno y otro bando, para demostrar su valentía, su condición de gran estratega y condición ecuánime al tratar al enemigo derrotado y a sus compañeros en el reparto del botín obtenido. La similitud entre las diversas manifestaciones épicas no sólo viene dada por el tratamiento de los personajes principales, sino también por la utilización de elementos expresivos comunes a la hora de relatar los sucesos acaecidos en la batalla. Según José Julio Martín Romero, esos «tópicos de guerra» ${ }^{4}$ funcionan en un doble sentido, pues «forman parte del conjunto de probabilidades que ofrece el arte de la guerra propia del género caballeresco, esto es, funcionan como la realización de una serie de posibilidades teóricas que ofrece la tradición literaria», y «en el plano textual, funcionan como unidades de construcción, una especie de material literario preestablecido que le sirve al autor para componer el relato del combate» (Martín Romero, 2006: 302).

\footnotetext{
${ }^{4}$ Según Martín Romero (2006: 314), la lista de tópicos, formada más por imitación que por imperativos retóricos, se compone de los siguientes elementos: caballeros cabalgan a toda prisa, como si la tierra temblara; las lanzas se quiebran, se hacen astillan o vuelan; tras el primer encuentro de lanzas, vuelven con ligereza sobre sus caballos; tras perder las lanzas, «comienza su hermosa batalla»; las armas resultan destrozadas y sus piezas terminan sembradas por el suelo; los golpes hacen que los guerreros bajen las cabezas hasta los pechos se inclinen; el ruido resulta atronador; salen centellas en los yelmos a causa de los golpes; la batalla se prolonga durante largo rato; no se percibe mejoría ni cansancio en los contendientes; tras un descanso, comienzan de nuevo con igual o mayor vigor, aprovechándose más de fuerza que de destreza; los testigos están admirados -e incluso asustados- de la crueldad de la lucha; los guerreros admiten la dureza del contrario e incluso se dicen que nunca han combatido contra otro igual; crece la ira de cada guerrero al ver que el contrario resiste tanto tiempo.
} 
La experiencia de la guerra aparece en los textos épicos como condición necesaria, y casi imprescindible, para que sus protagonistas aparezcan revestidos de la aureola mítica que les suele acompañar, pues, como ha señalado César Domínguez (1998: 160), «la biografía heroica del caballero se articula mediante la sucesión de tipo bélico», y «la acumulación de actividades guerreras victoriosas perfilan el currículo del héroe y determinan su fama para la posteridad». La demostración de valor e ingenio en la batalla es elogiada en los poemas épicos y acostumbra a ser uno de los requisitos que los personajes han de cumplimentar para certificar su ascenso social y su acceso al poder. No en vano, Maurice Bowra señaló en su clásico estudio Heroic Poetry que el tema central de la épica heroica era la persecución del honor a través del riesgo. Según Johan Huizinga, el ideal caballeresco que subyace a esta percepción del enfrentamiento bélico, presente en toda la cultura medieval occidental y traspasada al hombre del Renacimiento, no es más que un modelo con el que dar sentido una realidad incomprensible:

La guerra era, las más de las veces, un proceso crónico de incursiones y correrías aisladas y diseminadas sobre un gran territorio, la diplomacia, un instrumento muy complicado y deficiente, regido en parte por ideas tradicionales muy genéricas y en parte dominado por una confusión inextricable de pequeñas cuestiones jurídicas. Incapaz de descubrir en esto una verdadera evolución social, la historiografía se apoderó de la ficción del ideal caballeresco, para reducirlo todo por medio de ella a un hermoso cuadro de honor de príncipes y de virtud de caballeros, a un lindo juego de nobles reglas y crear, por lo menos, la ilusión de un orden (Huizinga, 1984: 95).

Esta idílica concepción del valor y de su demostración en el enfrentamiento se explica, entre otras cosas, por la consideración de la caballería y las órdenes militares como una forma superior de vida, manifestada según el propio Huizinga en la artificiosidad de lo heroico que rodea toda la vida cortesana, repleta de torneos, duelos $\mathrm{y}$, en general, exhibiciones de valor. La utilización de metáforas y juegos expresivos relacionados con la experiencia bélica en la poesía y el hecho de que el soldado-poeta -personificado en figuras como Don Juan Manuel, Jorge Manrique o Garcilaso de la Vega- sea uno de los personajes prototípicos de la época subrayan la sublimación de la guerra, pues, como manifestó Claudio Guillén (2006: 248), «cada era tiene sus protagonistas literarios, que al parecer representan simbólicamente las premisas, aspiraciones y nostalgias del momento». Una cita obtenida de Le Jouvencel, texto biográfico de Jean de Bueil, soldado combatiente con las tropas de Juana de Arco durante el siglo XV, así lo pone de manifiesto:

Cosa grata la guerra... ¡Se quieren tanto unos a otros en la guerra! Cuando se considera justa la propia causa y se ve combatir bravamente a la propia raza, las lágrimas vienen a los ojos. El corazón leal y piadoso siente la dulzura de ver al amigo que expone valientemente su cuerpo (Huizinga, 1984: 106, n. 4). 
3. Convertida con el paso del tiempo en tópico, la visión que identifica a la guerra con un acto heroico subraya su condición ineluctable. El fenómeno bélico es interpretado así como un acontecimiento del que nadie es capaz de sustraerse, como una prueba con la que necesariamente hay que enfrentarse y como una forma de acción valerosa que revela la esencia de la vida y del hombre. No obstante, fue a partir del siglo XIX cuando el modo de representar la guerra en la literatura fue modificado, reduciendo la importancia de los tradicionales modelos basados en el heroísmo y el carácter ejemplar y catártico del conflicto. Semejante cambio coincidió con el periodo de transición entre la historiografía positivista clásica y la tendencia, plenamente posmoderna, de cuestionar las versiones oficiales de los hechos e incluso sus procesos de representación. Coincidiendo con la consolidación de los campos intelectual y artístico, los escritores fueron por primera vez en la historia portadores de un discurso capaz no sólo de replantear la tradicional singularidad de las interpretaciones, sino también de dar -gracias a la independencia adquirida en los procesos descritos por Pierre Bordieu en el desarrollo del "campo literario"- una versión diferente de los sucesos. De este modo, su posición queda establecida como puente entre la historiografía que dice representar la verdad de los hechos y aquélla basada en la ambigüedad y en el caos que marcan los acontecimientos históricos. Tal modificación extendió sus efectos a la narración de las contiendas bélicas.

El novelista francés Stendhal, cuya concepción realista de la novela quedó plasmada en su ya legendaria sentencia «la novela es un espejo que ponemos en el camino», marcó un hito en la forma de reflejar literariamente los conflictos bélicos con la publicación, en 1839, de La cartuja de Parma. El argumento de la obra, grosso modo, se ocupa de las peripecias de un joven idealista, Fabricio del Dongo, durante los últimos años de dominio napoleónico en Europa. Al narrar en los primeros capítulos de la obra la experiencia vivida por el protagonista en la batalla de Waterloo, Stendhal condiciona el relato bélico a la dinámica textual, representada por la biografía del personaje principal. Junto a esa subordinación, es perceptible en esos pasajes de la novela la intención del autor por mostrar el carácter confuso y desorganizado de toda guerra gracias a una hábil utilización del punto de vista que le permite, pese a la omnisciencia del narrador, relatar únicamente lo percibido por Fabricio, con lo que la información que reciben los lectores coincide con la percepción del protagonista. De ese modo, la narración de los sucesos acaecidos en Waterloo transmiten una sensación de caos similar a la que parece dominar al personaje, incapaz de entender qué está ocurriendo exactamente a su alrededor y de dar un sentido global a los acontecimientos que está viviendo. Como dijo Jean Norton Cru (1929: 33), «Stendhal tenía demasiada sensatez 
para no ver que un testigo, si bien puede narrarse a sí mismo, no puede testimoniar en nombre de tres ejércitos enfrentados». De hecho, el texto «no informa sobre el combate, sino que más bien desinforma, desorienta y caotiza, compenetrándose con la visión interna de Fabricio", con lo que puede ser calificado incluso como "texto deceptivo" (Andrade-Boué, 2005: 23), tanto por las limitaciones de la visión de Fabricio, que imponen una mirada obligadamente elidida a la realidad bélica, como por la ruptura del horizonte de expectativas que, como integrante de la tradición bélica, supone:

[Fabricio] oyó a su lado un grito seco; eran dos húsares que caían heridos por balas de cañón; y cuando los miró ya habían quedado atrás a veinte pasos de la escolta. Lo que le pareció horrible fue un caballo ensangrentado que se revolcaba en la tierra labrada, pisándole sus propios intestinos; quería seguir a los demás. La sangre corría por el lodo.

-¡Ah!, ya estoy por fin el pleno fuego, dijo. He visto el fuego, repetía con satisfacción. Ya soy un verdadero militar. En este momento iba la escolta a todo correr, y nuestro héroe comprendió que las balas de cañón eran las que hacían saltar la tierra por todas partes. En vano miraba hacía el sitio de donde venían las balas de cañón; no veía más que el humo blanco de la batería a una distancia enorme y entre el ruido constante e igual que producían los cañonazos, parecíale oír descargas mucho más cercanas; no entendía absolutamente nada (Stendhal, 1989: 70).

El impacto que se siente en el protagonista de La cartuja de Parma no sólo viene provocado por el caos inherente a toda batalla y por la falta de perspectiva que para juzgar cualquier sucesión de acontecimientos tiene quien los está protagonizando, sino también por el hecho de constatar que la guerra tiene poco que ver con la imagen sublimada que de ella se ha dado en la literatura y el resto de las artes. De hecho, la visión que el protagonista tiene está mucho más cercana a la leyenda que a la realidad, como es gráficamente puesto de manifiesto en el parlamento a través del que Fabricio anuncia a sus familiares su intención de alistarse en el ejército de Napoleón:

De pronto, a una altura inmensa y a mi derecha, vi un águila, el pájaro de Napoleón; volaba majestuosamente hacia Suiza y por consiguiente hacia París. Pues yo también, me dije al momento, atravesaré la Suiza con la rapidez de un águila e iré a ofrecerle a ese gran hombre poca cosa, pero, en fin, lo que puedo ofrecerle, la ayuda de mi débil brazo. Él quiso darnos una patria, él tuvo afecto por mi tío. En el mismo instante, estando el águila aún visible, mis lágrimas se secaron por un singular efecto; y la prueba de que esta idea viene de arriba es que en el mismo momento, sin discutir, tomé mi resolución y percibí claramente los medios de llevar a cabo este viaje. [...] Y yo, dije para mí, hijo aún desconocido de esa madre desgraciada, yo partiré, yo iré a morir o a vencer con ese hombre, señalado por el destino, y que quiso purificarnos y librarnos del desprecio con que nos miran aún los más esclavos y viles habitantes de Europa (Stendhal, 1989: 55).

Similar visión idealista a la de Fabricio mantiene Henry, el protagonista de La roja insignia del valor, novela compuesta a finales del siglo XIX por Stephen Crane con los sucesos de la Guerra de Secesión norteamericana como telón de fondo. Al igual que en la novela de Stendhal, en la obra del autor estadounidense -responsable también de Heridas bajo la lluvia, conjunto de relatos sobre la Guerra de Cuba, a la que acudió 
como corresponsal de prensa $a^{5}$ aparece un personaje principal con una visión del mundo en general y de la guerra en particular condicionada por la interpretación épica del arte $\mathrm{y}$, en concreto, de la literatura:

Había soñado con batallas toda su vida, con vagos y sangrientos conflictos cuyo fuego y devastación le sobrecogieron el ánimo. Se había imaginado en numerosas contiendas. Había fantaseado con la idea de que las gentes hallaban seguridad bajo la sombra de su valor y su mirada de lince. Pero, despierto, veía las batallas como manchas sangrientas en las páginas del pasado. Las tomaba por cosas del ayer, asociadas a fabulaciones de pesadas coronas y altos castillos [...]. Había leído sobre marchas, asedios, conflictos, y había soñado presenciar todo aquello con sus ojos. Su agitada mente había dibujado grandes cuadros de extravagante colorido, refulgentes de hazañas que quitaban el aliento [...]. Hacía ya mucho tiempo que había perdido la esperanza de presenciar una batalla al estilo griego [...]. Había deseado alistarse muchas veces. Los relatos sobre grandes gestas zarandeaban el país. Podían no ser precisamente homéricas, pero aún así parecían gloriosas (Crane, 2007: 20).

También se evidencia en la obra el modo en que el protagonista se ve influido por «los periódicos, los cotilleos del pueblo [y] sus propias fabulaciones, [que] le habían entusiasmado hasta extremos incontrolables» (Crane, 2007: 21). La velada crítica que Crane realiza a la labor propagandística llevada a cabo por los medios de comunicación americanos durante la contienda precedió a la realizada por muchos de los autores que participaron en la I Guerra Mundial. Escritores como Remarque o teóricos como Norton Cru, combatientes ambos en el conflicto que asoló Europa entre 1914 y 1918, llegaron a manifestar que una de las razones que llevaron a componer sus obras -testimonial en el primer caso y académica en el segundo- fue la necesidad de rebatir las informaciones que los periódicos estaban dando a sus respectivas sociedades -alemana y francesa-. Frente a la imagen del conflicto que daban los medios de comunicación, en la que los correspondientes ejércitos nacionales siempre aparecían victoriosos sin apenas víctimas y los soldados luchaban con orgullo por su bandera y su patria, estos autores -y otros muchos- ofrecieron una interpretación devastadora del conflicto, presentado como una "trampa mortal" a la que los gobiernos enviaban a miles de jóvenes.

El carácter ensoñador de Henry tiene como contrapunto el pragmatismo del personaje de su madre:

\footnotetext{
5 Aunque todos los cuentos incluidos en la compilación parecen tener la memoria de las experiencias vividas por Crane en la isla caribeña como elemento activador, sólo uno de ellos -"Recuerdos de una guerra"- adopta tono y forma aparentemente autobiográficos al estar narrado por un periodista que acompaña a una de las divisiones que van a batirse en combate. El relato muestra el carácter complejo y caótico de la toda guerra al ser el narrador incapaz de dar cuenta de forma fidedigna de lo sucedido. El carácter inefable de los sucesos bélicos y, sobre todo, la ausencia de una lógica que pueda explicar el desolador panorama de barbarie y destrucción que tiene ante sí provoca la imposibilidad de narrar lo experimentado: «El episodio había terminado. Y podéis estar seguros de que no os he contado prácticamente nada, nada de nada, de nada» (Crane, 2006: 128).
} 
La recreación literaria de la experiencia bélica: de los modelos clásicos...

Su madre le había desalentado. Mostraba cierto desprecio hacia la calidad de su ardor guerrero y su patriotismo. Era capaz de sentarse tranquilamente y, sin aparente dificultad, enumerar cientos de razones por las que resultaba mucho más necesario en la granja que en campo de batalla.

-Madre, me voy a alistar.

-Henry, no seas tonto -le contestó su madre.

[...] Sin embargo, se había rebelado con firmeza contra aquella postura que pretendía palidecer el color de sus ambiciones [...]. A la mañana siguiente se dirigió a un pueblo que se encontraba cerca de la granja de su madre y allí se alistó en una compañía que estaba formándose. Cuando volvió a casa su madre estaba ordeñando una vaca pinta. Otras cuatro esperaban.

-Madre, me he alistado -le anunció, cohibido.

Se produjo un silencio breve.

-Que se haga la voluntad del Señor, Henry -respondió ella finalmente, y continuó ordeñando la vaca pinta.

[...] Le decepcionó que no le dijera nada sobre "volver con su escudo o sobre él". Pero las palabras de ella arruinaron sus planes. [Su madre] continuó pelando patatas con obstinación (Crane, 2007: 20-21).

Además de mostrar el contraste entre los dos personajes -y, con ello, entre dos formas diferentes de concebir el conflicto bélico-, el pasaje expone la anteriormente señalada influencia de las lecturas clásicas en las construcciones mentales de Henry. Así, se cita la frase que típicamente empleaba la épica griega para referirse a la despedida que se hacía a los soldados que se dirigían a la guerra-«volved con el escudo o sobre él»-. Con semejante afirmación se evidenciaba la necesidad de emplearse con valentía en la batalla, tanto para regresar como héroes victoriosos como para morir con honor y dignidad en combate.

Como en la relación entre Don Quijote y Sancho, mito y realidad quedan enfrentados a través del idealismo de uno y la mundana personalidad de la otra. Esta dualidad - perceptible en el propio título de la obra, en el que la referencia a la roja insignia del valor no es sino una alusión a la sangre- permanece activa durante la novela al confrontar Crane constantemente el filtro romántico a través del que el protagonista percibe la guerra con la realidad, repleta de barro, sangre y temor, que supone la participación en ésta:

Había imaginado la guerra como una serie de luchas a muerte con poco tiempo para comer y dormir; pero desde que su regimiento llegó al campamento, el ejército no había hecho otra cosa que permanecer con los brazos cruzados y tratar de guarecerse del frío [...]. Los veteranos [...] hablaban de humo, fuego y sangre [...]. Un conato de miedo invadía su mente. A medida que su imaginación le proyectaba en la batalla, contempló pavorosas posibilidades [...]. Recordó sus visiones épicas de gloria, pero ante la intuición del tumulto que se avecinaba, sospechó que aquellas imágenes eran imposibles (Crane, 2007: 23-25).

Gracias a la utilización de la figura del narrador omnisciente y al manejo del punto de vista narrativo, Stendhal y Crane comparten su intención de desacreditar la visión épica y heroica que la literatura acostumbraba a dar de las batallas con la crudeza de la realidad, para concluir que «la guerra no era, pues, ese noble y unánime vuelo de almas 
amantes de la gloria, que [Fabricio] se había figurado leyendo las proclamas de Napoleón» (Stendhal 76). Así lo comprueba el personaje principal de La cartuja de Parma al sentirse incapaz de reconocer entre el gentío de una división de infantería al propio emperador, el hombre por el que ha decidido arriesgar su vida combate, y ser engañado, y posteriormente burlado, por soldados que luchan en su mismo bando:

Además del dolor moral de haber sido indignamente robado y traicionado, otro dolor moral le torturaba a cada instante: se moría de hambre. Después de haber andado o mejor dicho corrido durante diez minutos, vio con gran alegría que el cuerpo de infantería [...] se detenía para formar. Algunos momentos después encontrábase entre los primeros soldados:

-Camaradas, ¿podríais venderme un pedazo de pan?

-¡Anda, ése nos toma por panaderos!

Estas palabras duras y la burla del general que siguió fueron para Fabricio un mazazo (Stendhal, 1989: 76).

La fuerza de este posicionamiento crítico con la guerra desemboca en un discurso antibelicista que, lejos de imponerse por la visión política o ideológica de los autores, es generado por los propios recursos narratológicos empleados. A la restricción focalizadora que obliga a presentar la guerra ante el lector como una sucesión de fenómenos inconexos -e incluso absurdos- caracterizados por su elevado nivel de violencia se suma el modo en que son descritos los personajes de ambas novelas. Se define a Fabricio y a Henry como jóvenes idealistas ensoñadores e inexpertos enfrascados en la contienda por su ciega fe en conceptos relacionados con el heroísmo y el honor. Partiendo de la valoración afectiva que el público puede establecer con los personajes a través de esa presentación, la estrategia narrativa «prepara otra consecuencia [...] que va a transformarse en [valoración] racional: la guerra siega vidas de jóvenes como éste, luego es mala» (Andrade-Boué, 2005: 24).

De este modo queda descubierta la potencialidad destructora del fenómeno bélico, capaz de quebrar vidas inocentes de jóvenes ensoñadores y de hacer olvidar «todo lo que se ha aprendido acerca de las reglas del honor» para «hacer volver al instinto o, mejor dicho, a los recuerdos de la primera infancia» (Stendhal, 1989: 103). Bajo esta concepción, que supone identificar la guerra con el comportamiento animal y salvaje, en La cartuja de Parma subyace la cosmovisión hobbesiana según la cual la legalidad y la justicia ética son necesarias para que el ser humano, violento y egoísta de forma innata, pueda vivir en paz y armónica convivencia. Además de criticar la capacidad de degradación de la guerra, existe en las dos novelas una intención crítica con la organización y los modos de conducta de los ejércitos. Si en la obra del autor francés el ataque a la vida militar se centra en su falta de compañerismo y el egoísmo, en La roja insignia del valor se cuestiona la rigidez de las normas a las que han de ceñirse los soldados -que hace aburrida y desesperante la vida en el frente- y, sobre todo, el papel de las autoridades en el proceso de manipulación de los individuos. Por eso puede 
afirmarse que -a pesar de la similitud de su reflejo literario de la experiencia bélica- la visión antropológica de la obra de Crane es diametralmente opuesta a la de Stendhal, pues se basa en las ideas roussenianas de la inocencia innata del hombre y de la responsabilidad del contexto en el proceso de transformación y abandono de la primigenia bondad. De ahí que la novela del escritor estadounidense mantenga cierto carácter pionero dentro de la literatura bélica, al vertebrar una crítica hasta entonces inédita a los causantes de la guerra ${ }^{6}$ por llevar a ella a una masa de población anónima e inocente. La presentación de los personajes de los soldados como seres inertes en manos de las maquinarías estatales se detecta en el hecho de que Crane los denomina con adjetivos referidos a su físico o a su personalidad -así, se habla del «soldado alto»o del «soldado gritón»-, prescindiendo de usar nombres propios. Incluso para referirse a Henry acostumbra a utilizar el sintagma nominal «el joven». De este modo se evidencia la consideración de los miembros del ejército de meros elementos de una masa que difumina los contornos de personales hasta hacerlos intercambiables y, con ello, prescindibles. El destino colectivo se impone por completo al personal, por lo que el valor de la vida queda totalmente desvirtuado:

Se dio cuenta de que le sería imposible escapar del regimiento. Estaba atrapado en su interior. Y había férreas normas de tradición y ley por los cuatro costados. Se hallaba en una caja de movimiento. Mientras sentía esto, se le ocurrió que en realidad él nunca había querido ir a la guerra. No se había alistado por libre voluntad. Un gobierno despiadado le había empujado a ello. Y ahora lo conducían al sacrificio (Crane, 2007: 41).

El desolador panorama bélico que se muestra en ambas novelas se ve acrecentado por la continua presencia de la muerte, elemento habitual en toda la literatura bélica cuyo tratamiento en La cartuja de Parma y en La roja insignia del valor, sin embargo, dista de ser convencional. Lejos de ser presentada como un acontecimiento heroico y admirable, la muerte en combate se expone de forma tremendamente real, sin obviar su dosis de patetismo y crueldad:

Fabricio no había andado quinientos pasos cuando su jamelgo se paró en seco: un cadáver obstruía el sendero, horrorizando por igual al caballo y al jinete. Fabricio estaba helado. Lo que más le conmovía era la suciedad de los pies de ese cadáver, ya despojado de sus botas y de todo, no quedándole más que un pantalón malo manchado de sangre [...]. Una bala, que entró junto a la nariz, había salido por la sien opuesta desfigurando al cadáver de forma horrible; tenía abierto un ojo (Stendhal, 1989: 65).

\footnotetext{
${ }^{6}$ La crítica de Crane no se limita a la actuación de las autoridades políticas, sino que también se ensaña con las militares y a su nula preocupación por la vida de los soldados de sus regimientos: «Las sombras del bosque le resultaron temibles. Estaba convencido de que en ese paisaje acechaban huestes de mirada peligrosa. Le asaltó la idea repentina de que los generales no sabían lo que estaba haciendo. Todo era una trampa. Esos bosques se erizarían pronto con los cañones de los rifles. Brigadas de hierro los sorprenderían desde la retaguardia. Iban a morir. Los generales eran idiotas. El enemigo aplastaría a toda la formación. Miró exaltado a su alrededor, esperaba ver la llegada furtiva de la muerte» (Crane, 2007: 43).
} 
De forma más directa, aunque menos gráfica, Stephen Crane mostró también su rechazo hacia las ideas de quienes buscaban el heroísmo a través de la muerte en el campo de batalla:

\begin{abstract}
Ahora [Henry] podía echar la vista atrás y repasar la ampulosidad y la pompa de sus antiguas creencias y verlas exactamente tal y como eran. Se sintió feliz de darse cuenta de que ahora las despreciaba. [...] Había estado buscando una muerte grandiosa y descubrió que, después de todo, sólo existía un tipo de muerte. Era un hombre (Crane, 2007: 189).
\end{abstract}

Guerra y paz refleja, combinando también, al igual que La cartuja de Parma, elementos de los mundos real y ficcional verosímil (Albaladejo, 1986: 49-66) -y generando por tanto una recepción cuasipragmática (Stierle, 1987: 87-143)-, los sentimientos que se generan al estar en medio de un campo de batalla. El miedo ante lo desconocido, la sensación de no saber con exactitud lo que está ocurriendo alrededor y la constante presencia de la muerte como inmediato horizonte vital están presentes en las páginas que la obra de Lev Tolstoi dedica a recrear, con detalle y prolijidad de datos, la campaña napoleónica en Rusia:

El enemigo había dejado de disparar y podía sentirse aún más claramente la precisa, amenazadora, inexpugnable y perceptible línea que separaba a los dos ejércitos enemigos. Un paso más allá de esa línea, que recordaba a la línea que separa a los vivos de los muertos, y se encuentra un tormento desconocido y la muerte. ¿Y qué hay allí? ¿Quién hay allí? [...] Nadie lo sabe y lo desean saber y es terrible cruzar esa línea y desean cruzarla y se sabe que tarde o temprano habrá que cruzarla y saber qué hay allí, al otro lado de la línea, del mismo modo que se ha de saber inevitablemente qué es lo que hay más allá de la muerte (Tolstoi, 2000: 255).

La narración de las batallas de Austerlitz o Borodino que aparece en la novela se asemeja a la efectuada por Stendhal. Los personajes que se baten combate no parecen dar sentido a nada de lo que ocurre a su alrededor, interpretado como un fenómeno inconexo y caótico dominado por la violencia y la destrucción, como se puede apreciar en este párrafo, referido a la experiencia en combate del capitán Tushin:

Se encontraba en un estado similar al delirio febril o a la borrachera. Tras los sonidos de sus cañones que le rodeaban por todas partes, tras el silbido y los golpes de los proyectiles enemigos, tras la visión de los artilleros sudorosos, sonrojados, que se apresuraban alrededor de las piezas, tras la vista de la sangre de soldados y caballos, tras la visión de los humos del enemigo en ese lado del que después de cada disparo volaba una bala que golpeaba la tierra, en un soldado, en una pieza o en un caballo, tras la visión de estos objetos, él se formaba en la cabeza su mundo fantástico en el que consistía su deleite en ese instante (Tolstoi, 2000: 339).

Al utilizar este planteamiento, la intención de Tosltoi, que conoció de primera mano los rigores de la vida militar -fue miembro del ejército ruso entre 1851 y 1856-, parece ser la de evidenciar la imposibilidad de expresar de manera fidedigna y completa 
un fenómeno tan complejo como la guerra. Sólo a través de una perspectiva cenital y panorámica capaz de relacionar y contextualizar todos los actos bélicos puede obtenerse una interpretación del fenómeno coherente. Por eso los personajes de su novela, como los de la de Stendhal, actúan del mismo modo que los soldados que, en la vida real, participan en un conflicto. Se limitan a pelear en el campo de batalla sin saber exactamente qué razones les han llevado hasta allí y sin tener una idea muy clara ni de qué es lo que están haciendo ni del desarrollo general de la guerra en la que están inmersos.

Junto a la preocupación del escritor ruso por reflejar la vida intrahistórica de las sociedades, representada en la masa anónima que forma los cuerpos militares, es detectable también en los capítulos dedicados a recrear el enfrentamiento entre los ejércitos francés y ruso el interés por mostrar la infrahumana consideración que se da por parte de las autoridades a los participantes en la contienda. Los soldados no son más que meros engranajes al servicio de los poderes militares, que los utilizan a su antojo sin mostrar consideración alguna por el destino de sus vidas. Así se puede observar cuando, después de narrar lo acontecido en el campo de batalla, Tolstoi relata cómo, mientras los miembros de un batallón de artillería curan sus heridas y entierran a sus compañeros muertos -panorama comparado con «un mar sombrío que oscila y se apacigua tras una tormenta» (Tolstoi, 2000: 345)-, los generales cenan plácidamente, más preocupados por la pérdida de dos cañones que por los cientos de bajas humanas sufridas (Tolstoi, 2000: 347-353).

4. La pertinencia de analizar desde la misma óptica La cartuja de Parma, La roja insignia del valor y Guerra y paz queda demostrada por su valor fundacional en el contexto de la literatura bélica. Tradicionalmente calificado como uno de los creadores de la tradición narrativa realista, Stendhal ha sido destacado por la crítica literaria por la novedad que supuso su forma de representar el conflicto bélico. Crane, por su parte, ha sido considerado pionero de una tradición en la que se inscriben escritores como John Dos Passos, James Jones, Norman Mailer o Ernest Hemingway, quien manifestó, en el prólogo a Hombres en guerra, la novedad que supuso para la literatura el tratamiento de la guerra que se hace en La roja insignia del valor. Presentada como un espacio caótico dotado de inusitados niveles de violencia, destrucción y dramatismo, la inclusión de la guerra en las obras de estos autores tiene una finalidad que va más allá de lo meramente argumental. La independencia de la que hacen gala en cuanto a su rol de creadores capaces de cuestionar las versiones de las fuentes del poder oficial y la progresiva importancia que la sociedad civil fue adquiriendo en la contienda generaron un nuevo discurso sobre la guerra, antecesor del compromiso y el antibelicismo característico de 
buena parte de la literatura del siglo XX y de la que son buenos representantes autores como Erich M. Remarque, Henri Barbusse, José Díaz Fernández o Robert Graves, quienes participaron activamente en algunos de los conflictos bélicos del siglo XX y dieron cuenta de ella. En ese nuevo discurso, la narración de los hechos está subordinada a una finalidad concreta. El relato bélico se convierte así en un relato funcional en el que el objetivo trasciende la recreación o descripción de los hechos y sirve para vehicular un sentido ideológico, político y ético.

\section{Bibliografía}

Albaladejo, Tomás (1986): Teoría de los mundos posibles y macroestructura narrativa. Alicante, Universidad de Alicante.

ANDRADE-BouÉ, Pilar (2005): "Funcionalidad del discurso de la guerra en la narrativa francesa del XIX”, Thèléme. Revista complutense de estudios franceses, 20, pp. 19-30.

BALLÓ, Jordi, y Xavier PÉREZ (2003): La semilla inmortal. Barcelona, Anagrama.

BARICCO, Alessandro (2002): Homero, Ilíada. Trad. Xavier González Rovira. Barcelona, Anagrama.

Borges, Jorge Luis (2002): Arte poética. Barcelona, Crítica.

CiCERón (1996): “A sus amigos”, en J. C. Fernández Corte y A. Moreno Hernández, eds., Antología de la literatura latina. Madrid, Alianza, pp. 210-212.

CRANE, Stephen (2006): Heridas bajo la lluvia. Trad. Juan Aparicio-Belmonte y María Ermitas Barrasa. Madrid, Rey Lear.

(2007): La roja insignia del valor. Trad. Juan Aparicio-Belmonte y María Ermitas Barrasa. Madrid, Rey Lear.

EstÉBAnEz CALDERÓn, Demetrio (2002): Diccionario de términos literarios. Madrid, Alianza.

DomínguEZ, César (1998): "De aquel pecado que le acusaban a falsedad: Reinas injustamente acusadas en los libros de caballerías (Ysonberta, Florencia, la santa Emperatriz y Sevilla)”, en Rafael Beltrán, ed., Literatura de caballerías y orígenes de la novela. Valencia, Universitat de Valencia, pp. 159-180.

GuILlÉn, Claudio (2006): Entre lo uno y lo diverso. Barcelona, Tusquets.

HeIZINGA, Johan (1984): El otoño de la Edad Media. Madrid, Alianza.

JÜNGER, Ernest (1987): Tempestades de acero. Trad. Andrés Sánchez Pascual. Barcelona, Tusquets.

(2005): Radiaciones I. Trad. Andrés Sánchez Pascual. Barcelona, Tusquets.

López Estrada, Francisco, y María Teresa LóPez García-Berdoy (1991): Poesía castellana de la Edad Media. Madrid, Taurus. 
LUBRICH, Oliver (2006): “Literatura y guerra. Ernst Jünger y las imágenes del horror”, Estudios filológicos alemanes: revista del Grupo de Investigación de Filología Alemana, 10, pp. 267-302.

MARTín Romero, José Julio (2006): “Aquellos furibundos y terribles golpes: la expresión del combate singular en los textos caballerescos", Revista de filología española, 86 (2), pp. 293-314.

MARTínEZ, Jesús Felipe (2003): "Si hay alguien más abyecto que el verdugo es el ayudante del verdugo", República de las letras: revista literaria de la asociación colegial de escritores, 79, pp. 137-148.

NORTON CRU, Jean (1929): Essai d' analyse et de critique des souvernirs de combattans édites en français de 1915 à 1928. París, Les Éttincelles.

SEbAld, W. G. (2003): Sobre la historia natural de la destrucción. Trad. Miguel Sáenz. Barcelona, Anagrama.

Stendhal (1989): La cartuja de Parma. Trad. Manuel García Morente. Madrid, Júcar.

STIERLE, Karlheinz (1987): “¿Qué significa «recepción» en los textos de ficción?”, en José Antonio Mayoral, ed., Estética de la recepción. Madrid, Arco Libros, pp. 87144.

Tolstol, Lev (2000): Guerra y paz. Trad Gala Arias. Madrid, DeBolsillo.

TooD, Oliver (2001): André Malraux: una vida. Trad. Encarna Castejón. Barcelona, Tusquets.

WeIL, Simone (1941): "La Odisea, o el poema de la fuerza", en http://hjg.com.ar/txt/sweil/sw_iliada.html (última consulta, 12-1-2009).

Wittgenstein, Ludwig (2006): Diarios secretos. Trad. Andrés Sánchez Pascual. Madrid, Alianza. 